International Journal of Current Advanced Research

ISSN: O: 2319-6475, ISSN: P: 2319 - 6505, Impact Factor: SJIF: 5.995

Available Online at www.journalijcar.org

Volume 6; Issue 4; April 2017; Page No. 3051-3053

DOI: http://dx.doi.org/10.24327/ijcar.2017.3053.0178

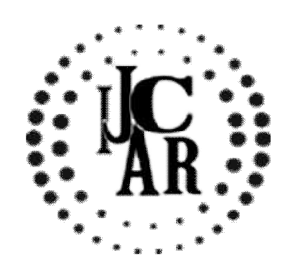

Research Article

\title{
AWARENESS ABOUT KNOWLEDGE, ATTITUDE AND PRACTICE AMONG DENTAL PRACTITIONERS REGARDING MANAGEMENT OF DENTURE INDUCED ULCERS
}

\author{
Nivetha G., Dhanraj M and Anandhi T
}

Saveetha Dental College Chennai-77

\begin{tabular}{l}
\hline A R T I C L E I N F O \\
Article History: \\
Received $16^{\text {th }}$ January, 2017 \\
Received in revised form $27^{\text {th }}$ February, 2017 \\
Accepted $22^{\text {nd }}$ March, 2017 \\
Published online $28^{\text {th }}$ April, 2017
\end{tabular}

\section{Key words:}

Denture, month ulcers, and knowledge.

\begin{abstract}
A B S T R A C T
Background: A mouth ulcer is an ulcer that occurs on the mucous membrane of the oral cavity. Mouth ulcers are very common, occurring in association with many diseases and by many different mechanisms, but usually there is no serious underlying cause. The two most common causes of oral ulceration are local trauma and aphthous stomatitisa condition characterised by recurrent formation of oral ulcers for largely unknown reasons.

Aim and Objectives: To create awareness about knowledge attitude and practice among dental practitioners regarding the management of denture induced ulcers.

Materials and Methods: A questionnaire was prepared which contained 15 questions and given to the 100 dental practitioners. The dental practitioners where from Chennai.The practitioners respond to all the questions in the given questionnaire. There were no dropouts in the study. The data was extracted and analysed.

Results: This study concluded $82 \%$ of dental practitioners had knowledge and attitude about the management of denture induced ulcers.

Conclusion: Dentures can cause oral mucosal lesions that could be prevented with postinsertion recalls to adjust defective dentures.
\end{abstract}

Copyright $\mathrm{C} 2017$ Nivetha G., Dhanraj M and Anandhi T. This is an open access article distributed under the Creative Commons Attribution License, which permits unrestricted use, distribution, and reproduction in any medium, provided the original work is properly cited.

\section{INTRODUCTION}

An ulcer is defined as damage in the mucous membrane or skin associated with loss of necrosis and surface tissueof epithelial tissue. A mouth ulcers is an ulcer that occurs on the mucous membrane of the oral cavity. They are very common occurring in associationwith many disease and by many different mechanisms. The most common causes for oral ulceration are local trauma and aphthous stomatitis, a condition characterised by recurrent formation of oral lesion for unknown reasons. They often cause pain and discomfort and may alter the person's choice of food. ${ }^{[1]}$ Denture-related oral mucosal lesions (DML) may represent acute or chronic reactions to denture plaque, yeast, constituents of the denture base material, poor retention and mechanical injury ${ }^{[2]}$ The lesions constitute a heterogeneous group with regard to pathogenensis. They include denture stomatitis, angular cheilitis, traumatic ulcers, denture irritation hyperplasia, flabby ridges, and oral carcinomas. ${ }^{[3]}$ Most of the lesions are caused by chronic infection (Candida albicans) or mechanical injury whereas allergic reactions to the denture base materials are uncommon. ${ }^{[4]}$ Diagnosis of the wide variety of lesions that occur in the oral cavity is an essential part of dental practice.The diagnosis and management of the patient with recurrent oral ulceration requires a systematic approach based

*Corresponding author: Nivetha G

Saveetha Dental College Chennai-77 on the principles of taking an adequate history, clinical examination etc. ${ }^{[5]}$ Denture-related mucosal lesions have been associated with denture plaque, Candida infection, poor denture retention and mechanical trauma. ${ }^{[13-14]}$ Dentures may predispose patients to the onset of mucosal lesions such as candidiasis, inflammatory or reactive hyperplasia and traumatic ulcer. ${ }^{[15]}$

\section{MATERIALS AND METHODS}

100 Dental practitioners from chennai participated in this survey. The questionnaire included 15 questions and the participants responded to the all questions in the questionnaire and there were no dropouts in the study. The data was extracted and analysed.

This questionnaire identified as

\section{Practitioners Detail}

1. Age

2. Gender

3. Generalist or specialist

4. Type of practice

5. Type of prosthesis

6. Commonest site for denture induced ulcers you had encounter.

IF YES,

1. Are caused by overextended denture base 
2. Can occur due to malocclusions

3. Can untreated ulcers leads to oral cancer.

4. Aware of medical management for denture induced ulcers

\section{Management}

1. Trimming over extended denture base or correcting the malocclusion can relieve denture induced ulcers.

2. Medication do you advise for denture induced ulcers.

3. Aware of possible complications induced by denture induced ulcers.

\section{Questionnaire}

The questionnaire was conducted based upon their knowledge, attitude, and practice about regarding the management of denture induced ulcers among Dental practitioners. This questionnaire was divided into 3 parts. The first part consist of the Dental practitioners general information which included their gender, year of qualification, postcode of practice, sector of practice, Generalist or specialist etc,. It help in finding of their practice level based on their personal data. The second part consist of question based on the cause of denture induced ulcers. It contains whether denture induced ulcers are caused by overextended denture base or malocclusion, whether untreated ulcers can leads to oral cancer and whether they aware of medical management for denture induced ulcers. The third part consists of question based on the management for denture induced ulcers. It contains whether trimming over extended denture base or correcting the malocclusion can relieve denture induced ulcers, mediation offered etc.

\section{RESULTS}

From the above study,it was concluded that all dental practitioners had knowledge about management of denture induced ulcers.About $70 \%$ of dental practitioners said that commonest site for denture induced ulcers are palatal mucosa, $20 \%$ of dental practitioners said that at gingiva and remaining $10 \%$ of dental practitioners said that palatal mucosa and gingiva [table 1].

Table 1

\begin{tabular}{cccc}
\hline & $\begin{array}{r}\text { Palatal } \\
\text { mucosa }\end{array}$ & Gingiva & Both \\
\hline $\begin{array}{c}\text { Dental } \\
\text { practitioners }\end{array}$ & $70 \%$ & $20 \%$ & $10 \%$ \\
\hline
\end{tabular}

Table 2

\begin{tabular}{cccc}
\hline & $\begin{array}{c}\text { Complete } \\
\text { denture }\end{array}$ & $\begin{array}{c}\text { Fixed } \\
\text { partial } \\
\text { denture }\end{array}$ & $\begin{array}{c}\text { Removable } \\
\text { partial } \\
\text { denture }\end{array}$ \\
\hline $\begin{array}{c}\text { Type of } \\
\text { prosthesis }\end{array}$ & $67 \%$ & $06 \%$ & $27 \%$ \\
\hline
\end{tabular}

Table 3

\begin{tabular}{cccc}
\hline & Yes & No & $\begin{array}{c}\text { Don't } \\
\text { know }\end{array}$ \\
\hline $\begin{array}{c}\text { Overextended } \\
\text { denture base }\end{array}$ & $75 \%$ & $25 \%$ & 0 \\
Malocclusion & $77 \%$ & $23 \%$ & 0 \\
\hline
\end{tabular}

About $67 \%$ of dental practitioners agree that the patients who are wearing complete denture had experienced denture induced ulcers [Table 2].75\% of dental practitioners felt that denture induced ulcers are caused due to overextended denture base and also $77 \%$ of dental practitioners agree that denture induced ulcers can occur because of malocclusion [Table 3]. $85 \%$ of dental practitioners said that trimming the overextended denture base or correcting the malocclusion can relieve the denture induced ulcers. Over $90 \%$ of dental practitioners were aware of possible complications induced by denture induced ulcers.
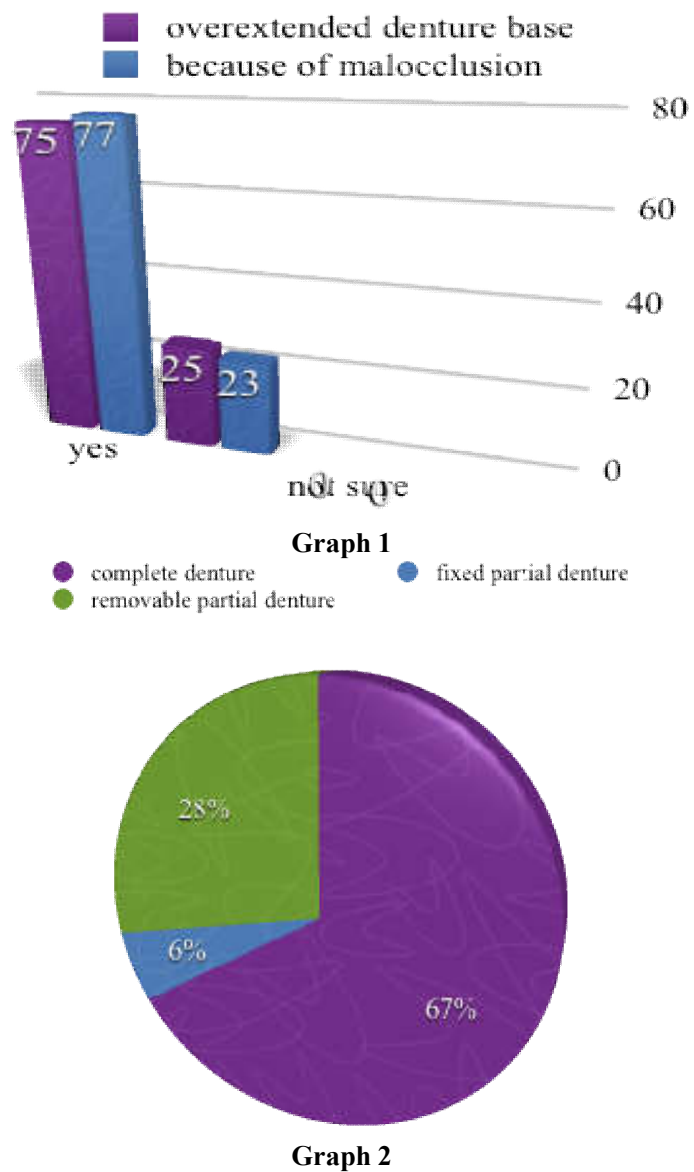

\section{DISCUSSION}

Removable dentures can injure oral tissues and the use of dentures is associated with a high frequency of oral mucosal lesions. ${ }^{[6]}$ Denture stomatitis is the most common condition which affects the palatal mucosa in about $50 \%$ of wearers of complete or partial removable dentures.Denture irritation hyperplasia, which is caused by chronic injury of the tissue in contact with the denture border, is present in about $12 \%$ of denture wearers. Flabby ridge, which is replacement of alveolar bone by fibrous tissue, is present in $10-20 \%{ }^{[7]}$

The frequency of all denture-related lesions increased with the length of denture use.Chronic irritation from ill-fitting or defective dentures has often been mentioned as a contributing factor in the development of oral cancer. ${ }^{[8]}$

Several lesions were more frequent in females than in males. This high frequency of lesions among females is not well understood. It has been suggested that it may be due to the fact that female patients wear their dentures more often and perhaps for longer periods of time for esthetic purposes.$^{[9]}$ However, this does not appear to be the complete answer, and another possible factor may be hormonal. Although further studies would be valuable to elucidate the possible hormonal 
role in DML, some authors ${ }^{[10]}$ have suggested that during or after menopause, there is atrophy of the oral cavity mucosa concomitant with decreased ovarian secretion. The thin atrophic oral epithelium offers little protection against various irritants, and is therefore more prone to develop an inflammatory reaction as a response to the chronic irritation by an ill-fitting denture. Other mucosal lesions occurred more frequently in males than in females, in disagreement with some authors ${ }^{[11]}$

Although denture wearing can improve the quality of life and restore masticatory function, poorly fitting dentures may cause oral lesions. An understanding of the DMLs and regular visits to the dentists are essential for denture wearers. DMLs can be prevented if denture wearers take proper care of their dentures and maintain good oral hygiene ${ }^{[12]}$

\section{CONCLUSION}

This study concluded that the knowledge and awareness regarding the denture induced ulcers was observed to be adequate among the dental practitioners.Dentures can cause oral mucosal lesions that could be prevented with postinsertion recalls to adjust defective dentures and provide information on cleaning methods and instructions on how to maintain oral tissues healthy.

\section{References}

1. "Ulcer on Merriam-Webster medical dictionary". Merriam-Webster, Inc. Retrieved 27 December 2012.

2. Vorvick LJ, Zieve D. "Mouth ulcers on MedlinePlus". A.D.A.M., Inc. Retrieved 27 December 2012.

3. Budtz-Jørgensen E. Clinical aspects of Candida infection in denture wearers. J Am Dent Assoc. 1978; 96: 474.

4. Budtz-Jørgensen E. Oral mucosal lesions associated with the wearing of removable dentures.J Oral Pathol. 1981; 10: 65.

5. Coelho CMP, Sousa YTCS, Dare AMZ. Denture related oral mucosal lesions in a Brazilian school of dentistry. J Oral Rehabil 2004; 31: 135-139.
6. Helft M, Cardash HS, Rones B, Ben-Ur Z. The prevalence of denture-related injuries in patients resident at two Israeli geriatric hospitals. Gerodontology. 1986; 5: 123.

7. Freitas JB, Gomez RS, De Abreu MH et al. Relationship between the use of full dentures and mucosal alterations among elderly Brazilians. J Oral Rehabil 2008; 35: 370-374.

8. Moskona D, Kaplan I. Oral lesions in elderly denture wearers. ClinPrev Dent 1992; 14: 11-14.

9. Cutright DE. The histopathologic findings in 583 cases of Epulisfissuratum. Oral Surg. 1974;37: 401

10. Buchner A, Calderon S, Ramon Y. Localized hyperplastic lesions of the gingiva: a clinicopathological study of 302 lesions. $J$ Periodontol. 1977; 48: 101.

11. Pinto-Coelho CM, Zucoloto S. Denture-induced fibrous inflammatory hyperplasia: a retrospective study in a School of Dentistry. Int J Prosthodont. 2000; 13: 1 .

12. Nevalainen MJ, Narhi TO, Ainamo A. Oral mucosal lesions and oral hygiene habits in the home-living elderly. J Oral Rehabil 1997; 24: 332-337.

13. Coelho CM, Sousa YT, Dare AM. Denture-related oral mucosal lesions in a Brazilian school of dentistry. $J$ Oral Rehabil 2004; 31: 135-139.

14. Freitas JB, Gomez RS, De Abreu $\mathrm{MH}$ et al. Relationship between the use of full dentures and mucosal alterations among elderly Brazilians. $J$ Oral Rehabil 2008; 35: 370-374.

15. MacEntee MI, Glick N, Stolar E. Age, gender, dentures and oral mucosal disorders. Oral Dis 1998; 4: 32-36.

\section{How to cite this article:}

Nivetha G et al (2017) ' Awareness About Knowledge, Attitude And Practice Among Dental Practitioners Regarding Management Of Denture Induced Ulcers', International Journal of Current Advanced Research, 06(04), pp. $3051-3053$. DOI: http://dx.doi.org/10.24327/ijcar.2017.3053.0178 